\title{
Outras verdades, muito extraordinárias
}

\author{
WALDECY TENÓRIO
}

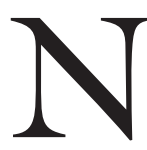

UMA PASSAGEM de Grande sertão: veredas, de Guimarães Rosa (1970), ${ }^{1}$ o narrador-protagonista recorda os dias durante os quais viveu num sítio, perto de um lugar chamado Currais do Padre, um lugar tão pobre que lá não havia nada, nem curral nem padre: "Mas o dono do sítio, que não sabia ler nem escrever, assim mesmo possuía um livro, capeado em ouro, que se chamava o 'Senclér das ilhas' e que pedi para deletrear nos meus descansos". E depois de ter lido o livro, diz o narrador que "nele achei outras verdades, muito extraordinárias" (p.287). O que se deseja neste ensaio é mostrar algumas verdades também extraordinárias que esperam ser acordadas pelo leitor de Grande sertão.

Comecemos por uma citação de Julia Kristeva (1969):

é necessário saber apesar de tudo se essa coisa que fala quando eu falo é que me implica totalmente em cada som que enuncio, em cada palavra que escrevo, em cada signo que faço, se essa coisa é realmente eu, ou um outro que existe em mim, ou ainda um não sei que de exterior a mim mesmo que se exprime através de minha boca em virtude de qualquer processo ainda inexplicado.

Logo depois de fazer essa afirmação, que poderia incriminá-la em flagrante delito de metafísica, Kristeva prudentemente se esquiva e corta o assunto, dizendo: "Mas não se vai responder aqui a esta questão". A verdade é que ela não vai responder "aqui" nem em lugar nenhum, justamente porque, para fazê-lo, seria necessário seguir o percurso que vai da lingüística à teologia, ou vice-versa, o que Kristeva não faria jamais.

Outro grande lingüista, A. J. Greimas, no entanto, se também adota uma atitude de prudência, e se também não faz o percurso teológico, pelo menos nos faz um sinal. Ele diz: "Talvez exista um mistério na linguagem” (apud Crossan, 1976).

Aproximando-se assim os dois textos, como estamos fazendo, parece que Greimas estaria respondendo a Kristeva. Mas isso não passa de suposição e, afinal, não é relevante saber, pelo menos no nosso caso, se teria havido ou não esse diálogo entre os dois. O relevante, aí sim, é o fato de Greimas, sendo quem é, ter podido dizer o que nos disse.

Agora, é mais ou menos evidente que a presença do advérbio "talvez" no início da frase, sob certo aspecto, diminui a força da afirmação de Greimas. Ele não diz: Há um mistério. Diz: Talvez haja. Mas vistas sob outro aspecto, as coisas se passam de maneira diferente. É que o advérbio confere ao pensamento de Greimas um tom claro-escuro, ou uma aura crepuscular, que o aproxima da 
idéia agostiniana de "cognitio verpertina", uma forma de conhecimento que se dá na penumbra da tarde - ou na dúvida de um "talvez".

Olhando dessa maneira, o advérbio dá outra nuança à frase, ainda mais se aceitarmos a fórmula de Jean Lacroix segundo a qual toda dúvida sugere uma crença superior. Eis por que o nosso ponto de partida é a fragilidade do "talvez" de Greimas.

É com isso em mente que abrimos a primeira página do romance. Como ele principia? Por um incipit famoso: "Nonada. Tiros que o senhor ouviu foram de briga de homem não". Essa voz que fala é a voz do narrador, que mais tarde saberemos tratar-se de Riobaldo, o protagonista da história. E aqui se insinua uma pergunta: A quem o narrador se dirige? Ou, nos termos de Roman Jakobson (1970), no ensaio "Lingüística e poética", quem é o destinatário nesse ato lingüístico de comunicação? A resposta é: Não sabemos.

Por duas razões. A primeira é que o emissor da mensagem só se refere ao destinatário de forma muito vaga, que absolutamente não dá para identificá-lo. "O senhor tolere" (p.9), "O senhor entenda" (p.10), "O senhor não duvide" (p.12), "Exponho ao senhor" (p.39), e assim em mil variantes, o tempo todo. De vez em quando, o narrador explora a função fática da linguagem, querendo saber se o outro está atento ao que ele diz, se o canal de comunicação continua aberto: "Hem?" "Hem?". O destinatário, no entanto, não diz nada, não responde, não reage às provocações do narrador.

É uma marca textual do romance. O narrador abre o coração, conta a sua vida, resgata lembranças, pensa, provoca, pergunta, implora uma resposta. Silêncio. Joga isca atrás de isca: "E como é mesmo que o senhor fraseia?" (p.57). Silêncio. "Invejo é a instrução que o senhor tem" (p.78). Silêncio. O leitor se aflige. Quem é essa Esfinge? Mas não se jogue a culpa no narrador, pois ele também não sabe quem é o destinatário de sua mensagem, e, como nós, está intrigado.

Tanto que já na segunda página do romance somos testemunhas de sua perplexidade, naquela passagem na qual ele está contando o que aconteceu no Andrequicé. Por lá passou um "moço de fora" e disse que, para fazer um determinado percurso, no qual qualquer jagunço gastava um dia e meio a cavalo, ele só precisaria de vinte minutos. E o narrador conta então o que ouviu de outras pessoas: "Tem gente porfalando que o Diabo próprio parou, de passagem, no Andrequicé".

Ora, ao pronunciar a palavra Diabo, o narrador, ele mesmo, tem um sobressalto, um frio na barriga, e, nesse momento, desconfia da própria pessoa a quem está se dirigindo:

Ou, também, quem sabe - sem ofensas - não terá sido, por um exemplo, até mesmo o senhor quem se anunciou assim, quando passou por lá, por puro divertimento engraçado?

A linguagem é cautelosa, como gato em cima de brasa, mas a suspeita está lançada. Será que o destinatário é o Diabo mesmo, ou tudo não passa de "prazido divertimento engraçado?". Lembrando Edgar Morin, o pensamento do romance 
é um pensamento complexo: "Deus existe mesmo quando não há. Mas o demônio não precisa de existir para haver" (p.49). Para quem se inventou no gosto de "especular idéia" (p.11), é assim que as coisas se passam: "Tudo tem seus mistérios" (p.221) e "natureza da gente não cabe em nenhuma certeza" (p.315).

Mas, afinal, esse destinatário suspeito, foi mesmo ele quem passou pelo Andrequicé? "Sei que não foi. E mal eu não quis. Só que uma pergunta, em hora, às vezes clareia razão de paz. Mas, o senhor entenda: o tal moço, se há, quis mangar" (p.10).

Por enquanto, o destinatário da mensagem está livre da suspeita de ser o tal moço, o Diabo. No entanto, a existência desse não está descartada, donde a presença da oração concessiva: "Se ele existe... quis mangar". Para desvendar esse mistério, podemos seguir a pista levantada por um mestre da crítica, Roland Barthes: em literatura, há muitos lugares de chegar, mas um só de partir: esse lugar é o texto. Voltemos então ao incipit do romance:

- Nonada. Tiros que o senhor ouviu foram de briga de homem não, Deus esteja. Alvejei mira em árvore no quintal, no baixo do córrego. Por meu acerto. Todo dia isso faço: gosto, desde mal em minha mocidade. Daí vieram me chamar. Causa dum bezerro: um bezerro branco, erroso, os olhos de nem ser - se viu; e com máscara de cachorro. Me disseram; eu não quis avistar. Mesmo que, por defeito como nasceu, arrebitado de beiços, esse figurava rindo feito pessoa. Cara de gente, cara de cão: determinaram - era o demo. Povo pascóvio. Mataram. Dono dele nem sei quem for. Vieram emprestar minhas armas, cedi. Não tenho abusões. O senhor ri certas risadas...

Desde o início do romance, e a última citação o comprova, sentimos a presença/ausência de Deus ou do diabo, sempre numa atmosfera de ambigüidade. É e não é, pode ser que seja, e se não for? E sempre alguma coisa desnorteia o leitor. O bezerro, ou seja, o demo, "figurava rindo". Do destinatário, o narrador diz que "ri certas risadas". E retorna a suspeita. Então o demo e o destinatário são a mesma pessoa? Hélio Pellegrino (1988) sugere que não, quando nos diz que o demônio, partidário dos sistemas, é muito sério, não conhece nossas alegrias, não sabe rir.

Por isso, quando o narrador diz "O senhor ri certas risadas", temos o direito de fazer um pequeno exercício de transleitura e ouvir a voz de Milan Kundera no famoso discurso de Jerusalém:

Gosto de imaginar que François Rabelais um dia ouviu o riso de Deus e foi assim que nasceu a idéia do primeiro grande romance europeu. Agrada-me pensar que a arte do romance veio ao mundo como eco do riso de Deus.

Então, quem é esse que figura rindo e esse que ri? Para falar como o próprio Riobaldo, "é aí que a pergunta se pergunta" (p.86). Em todo caso, permanecem ainda as duas pistas de nossa investigação. Pode ser o diabo, por que não? A literatura já esteve tantas vezes no Inferno. E além disso, a presença do diabo em qualquer romance seria evidente se ele não fosse um mestre do disfarce, aquele que se esgueira e passa despercebido, como na cena do Pacto. 
Do demo ? Năo gloso. Senhor pergunte aos moradores, Em falso receio, desfalam no nome dêle - dizem so : ôtent vôte t nåo... Quem muito se evita, se convive. Sentença num Aristides - oqu existe no buritizal primeiro desta minha măo direita, chamado a Veredada-Vaca-Mansa-de-Santa-Rita - todo o mundo crế : êle não pode passar em trếs lugares, designados : porque entåo a gente escuta um chorinho, atrás, e una vozinha que avisando : -" Ju já vou l Eu já vou 1..." que 6 o capiroto, o we-diga . E un Jisé Simpilicio - quer qualquer daqui jura êle tem um capeta em casa, mikdo satanazim, prêso obrigado a ajudar em tốda ganância que executa; razão que o Simpilifioio se empresa em vias de completar de rico. Apre, por 1sso dizem também que a bêsta pra $\hat{l} l e$ rupêia, nega de banda, não deixando, quando êle quer amontar... Superstiģão. Jisé Simpillicio e Aristides, mesmo estão se engordando, de assim năo-ouvir ou ouvir. Ainda o senhor estude : agora mesmo, nestes dias de época, tem gente porfalando que o Diabo próprio parou, de passagem, no Andrequicé. Un Mốço de fora, tería aparecido, e lá se louvou que, para aqui vir - normal, a cavalo, dum dia-e-meio - êle era capaz que s6 com uns vinte minutos bastava... porque costeava o Rio do Chico pelas cabecelras $t$ ou, também, quem sabe - sem ofensas - nåo terá sido, wor exemplo, até mesmo o senhor quem se anunciou assimphor

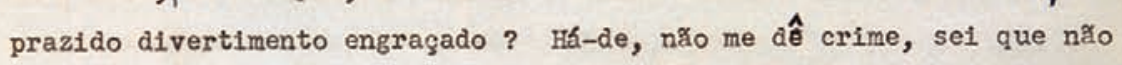
fo1. E mal eu não quis. So que uma pergunta, em hora, às vêezes clarếie razåo de paz. Mas, o serhor entenda : 0 tol mốço, se há, quis mangar. hem, ques) Pois, despontar o Rio pelas nascentes, será a mesma coisa que um se redobrar nos internos dêstê Bstado nosso, custante viagem de uns trếs meses

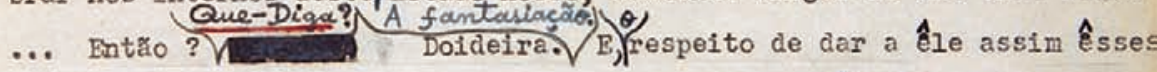
nomes de rebuço, é que é mesmo um querer invocar que êlle forme forma, compresenças :

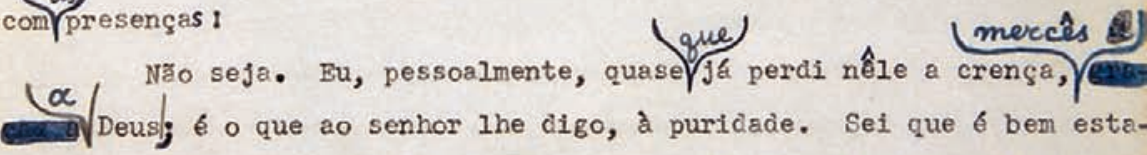
belecido, que grassa nos Santos-Evangelhos. Em ocasião, conversei com um rapaz seminarista, muito conoizente, conferindo no livro de rezas e revestido de paramenta, com uma vara de maria-preta na mão - proseou que ia adjutorar o padre, para extraírem o Cujo, do corpo vivo de una

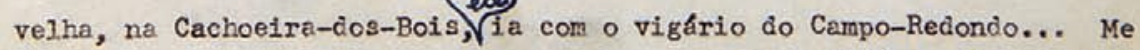
concebo. o senhor não é como eu ? Năo acreditei patavim. Compadre

Original datilografado, com correções manuscritas do autor, de Grande sertão: veredas. 


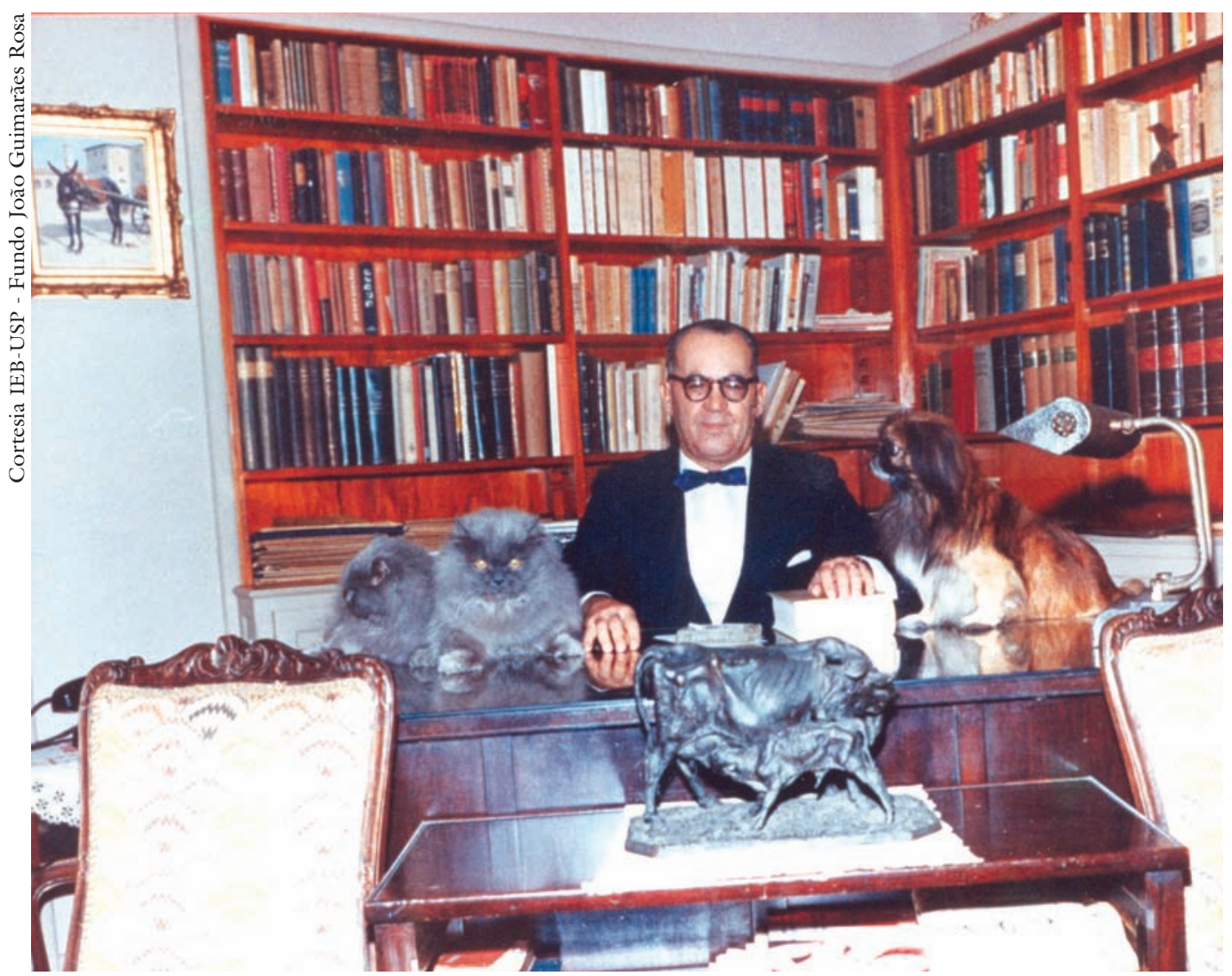

Guimarães Rosa em seu escritório, com seus animais de estimação, em Copacabana (RJ), 1958.

A segunda pista, já sabemos, é a seguinte: o destinatário enigmático é Deus. Mas como justificar essa hipótese? Bem, ele também é um mestre do disfarce, aparece e desaparece, Deus absconditus, age como o esgrimista de Kierkegaard: o adversário sente o golpe, é tocado, mas sempre num lugar muito diferente do que esperava. E, além disso, ele é sutil, a ponto de um teólogo como Karl Rahner ter podido defender a idéia de que o cristianismo é uma forma radical de agnosticismo. E de um Jack Milles ter dito que, de Deus, não se pode escrever uma biografia, mas uma teografia, que ele mesmo define como o movimento do discurso em direção ao silêncio. Desse modo, se o interlocutor de Riobaldo se disfarça, se esconde, silencia - e ri -, pode ser um disfarce de Deus, por que não?

Como, entretanto, estamos lendo um romance, o melhor caminho para comprovar a hipótese levantada é a própria linguagem. Tivemos alguma expectativa em relação a Kristeva, mas logo vimos que não podíamos contar com ela. Greimas, por sua vez, nos deu uma certa suspeita, mas só. E se procurássemos apoio em algum teólogo? Justamente G. Crespy (1970), que trabalha com a relação entre linguagem e teologia, vem nos dizer que nossas representações de Deus têm sempre um suporte cultural, de tal modo que, quando a cultura se transforma, elas também mudam. O que isso quer dizer, então? Que Deus existe na linguagem e é lá que devemos procurá-lo. Afinal, de Hesíodo a Heidegger, sabemos que a linguagem é a morada do ser. 
Peçamos, então, a ajuda de Jakobson (1970), num de seus ensaios mais significativos e de grande repercussão nos estudos literários, aquele, já citado, no qual o lingüista romeno discute os fatores e as funções da linguagem.

O que diz, em suma, esse texto? Não se vai repetir aqui o ensaio mas apenas recordar alguns pontos de sua estrutura básica. A comunicação lingüística exige que se dê a presença de três fatores: um remetente, uma mensagem, um destinatário. É necessário ainda que haja um contexto, um referencial comum e um código conhecido pelo destinatário. Daí decorrem as seis funções básicas que Jakobson distingue na comunicação verbal.

Podemos alinhá-las assim: a função emotiva, ou expressiva, que se caracteriza pela transmissão de conteúdos emotivos próprios do emissor; a função apelativa, que pretende influenciar o modo de pensar do receptor ou destinatário; a função referencial, também chamada informativa, que consiste na transmissão de um saber, um conteúdo intelectual de que se fala; a função fática, que estabelece, prolonga ou interrompe a comunicação; a função metalingüística, que verifica se emissor e receptor usam o mesmo código; e, por fim, a função poética, centrada sobre a própria mensagem.

Uma vez que estamos no universo da ficção, vale a pena recordar os pressupostos da função poética. Quando ela está presente? Quando a mensagem cria a sua própria realidade, que não se identifica com a realidade empírica. Della Volpe (1960) dá um exemplo a propósito dos nevoeiros londrinos: se eles estão presentes na obra de Dickens, é graças à palavra do romancista, a qual se basta a si própria. E Della Volpe pergunta: que palavra de geógrafo, de historiador ou de cientista é verdadeira por si mesma? O mesmo vale para as neblinas de Siruiz e para o mundo criado pela linguagem de Guimarães Rosa.

Há, no entanto, no ensaio de Jakobson uma passagem que às vezes se esquece e que devemos retomar por ser importante para a hipótese que estamos levantando. É quando, depois de explicar as funções da linguagem, ele diz: "Certas funções podem ser facilmente inferidas desse modelo", e aí vem o que interessa sublinhar: "Assim, a função mágica, encantatória, é sobretudo a conversão de uma pessoa ausente em destinatário de uma mensagem conativa". Portanto, quando fazemos de um ausente o destinatário de uma mensagem conativa, estamos realizando a função mágica da linguagem e entrando em contato com o Absoluto. Não é o que acontece em Grande sertão?

Ainda assim, porém, persiste o mistério sobre a identidade desse destinatário ausente. Entre ele e Riobaldo há, ao mesmo tempo, proximidade e distância: "O senhor é de fora, meu amigo mas meu estranho" (p.33). E, no entanto, Riobaldo sente por ele uma atração inexplicável. No começo do romance, não quer que o outro vá embora (p.22). Mais adiante, apesar do silêncio do destinatário, ele espera o diálogo: "Mais hoje, mais amanhã, quer ver que o senhor põe uma resposta" (p.87). E no final do romance, ele constata que a relação com o outro é sempre difícil: "O querer-bem da gente se despedindo como um riso e soluço" (p.442). 
Quem é esse que assim atormenta Riobaldo? Por artes mágicas, esse que se esconde nos interstícios da linguagem não poderia ser o diabo? Sim, já vimos isso, mas contra essa hipótese pesam os argumentos que levantamos antes, e pesa, sobretudo, o depoimento final do narrador: "O diabo não há! É o que eu digo, se for... Existe é homem humano". A última palavra do romance - "Travessia" - indica uma mudança.

A mudança se esclarece quando Riobaldo diz: "O sério é isto, da história toda - por isto foi que a estória eu lhe contei -: eu não sentia nada. Só uma transformação, pesável" (p.86). Ora, essa transformação que se dá por meio de um diálogo secreto - o dialogismo interior de Bakhtin - é a resposta que Riobaldo esperou durante o romance inteiro.

Mas então quem é esse cuja palavra pode transformar assim a vida do jagunço. Deus? Kristeva sugere, mas se esquiva; Greimas oferece uma pista, mas hesita. Crespy e Jakobson são mais convincentes, assim como Bakhtin. Mas o argumento decisivo para resolver a questão vem de Wolfgang Iser $(2005$, p.248), e pode ser formulado assim: Uma vez que Deus não pode ser nada, está destinado a ser no-nada, ou seja, nonada, justamente a palavra pela qual o romance principia.

"O senhor me diga: o senhor desconfiou de alguma arte, concebeu alguma coisa?" (p.408). Aqui está um segredo: "Nonada" é uma invocação, ou talvez uma prece, e o destinatário misterioso a quem o narrador se dirige é Deus. É a Deus, portanto, que ele narra toda a sua vida, numa confissão geral. E Deus, esse grande mestre do disfarce, escondido ali no romance desde o início, desde a primeira palavra, sem que nós o suspeitássemos!

Por isso, Riobaldo não precisa de "suma doutoração" (p.14) para nos dizer que "no sertão, o que é doideira às vezes é a razão mais certa" (p.217). Nem para nos lembrar que "um bom entendedor num bando faz muita necessidade" (p.302). Para quê? Para encontrar o que ele mesmo encontrou não nos "livros de estudo", mas no "Senclér das ilhas", e, enfim, para descobrir essa verdade muito extraordinária que acabamos de demonstrar. "Senhor o que acha?"

Nota

1 As citações feitas referem-se à edição mencionada nas Referências bibliográficas.

Referências bibliográficas

CRESPY, G. Essais sur la situation actuelle de la foi. Paris: Cerf, 1970.

CROSSAN, J. D. Incursion sobre lo articulado. Buenos Aires: Megalopolis, 1976.

DELLA VOLPE, G. Critica del gusto. Milano: Feltrinelli, c1960.

ISER, W. Rutas de la interpretación. México: Fondo de Cultura Económico, 2005.

JAKOBSON, R. Lingüistica e comunicação. São Paulo: Cultrix, 1970. 
KRISTEVA, J. História da linguagem. Lisboa: Edições 70, 1969.

MORIN, E. Introduction à la pensée complexe. Paris: ESF Éditeur, 1990.

PELLEGRINO, H. A burrice do demônio. Rio de Janeiro: Rocco, 1988.

ROSA, J. G. Grande sertão: veredas. Rio de Janeiro: José Olympio, 1970.

RESUMO - QUEM É A personagem enigmática a quem se dirige Riobaldo? Partindo de conceitos desenvolvidos pelo teólogo G. Crespy, por lingüistas como Julia Kristeva, A. J. Greimas e Roman Jakobson, assim como pelo crítico Wolfgang Iser, o autor deste ensaio percorre as páginas de Grande sertão: veredas para descobrir "outras verdades, muito extraordinárias": "Nonada" é uma invocação ou uma prece e a personagem enigmática do romance é Deus, a quem Riobaldo narra toda a sua vida, transformando a narrativa numa confissão geral. "Senhor o que acha?"

PALAVRAS-CHAVE: Guimarães Rosa, Ficção, Teologia.

ABSTRACT - WHO IS THE enigmatic character to whom Riobaldo speaks? Starting from the concepts developed by the theologian G. Crespy, by linguists such as Julia Kristeva, A. J. Greimas and Roman Jakobson, as well as by the critic Wolfgang Iser, the author goes through the pages of Grande sertão: veredas to discover "other, very extraordinary, truths": "Nonada" is an entreaty or prayer and the novel's enigmatic character is God, to whom Riobaldo narrates all his life, transforming the narrative in a general confession. "Sir, what do you think?"*

* In Portuguese, the polite form that shows respect "Senhor" is used to address both: a man who is older, richer or more powerful and God. So, the same sentence could be translated in English to: "Lord, what do thou think?"

KEYWORDS: Guimarães Rosa, Fiction, Theology.

Waldecy Tenório é professor doutor, pesquisador do IEA-USP na área de Estudos Interdisciplinares de Literatura e autor, entre outros, de A bailadora andaluza: a explosão do sagrado na poesia de João Cabral. @ - waldecytenorio@uol.com.br

Recebido em 12.9.2005 e aceito em 5.4.2006. 